\title{
CRITICAL COMPARISON OF GROUND MOTION ATTENUATION FORMULAE FOR RECENT EARTHQUAKE DATA
}

\author{
Achyutha Bharadwaj $S^{1}$, Manasa ${ }^{2}$, Rajaram vailaya $S^{3}$, Sumanthu $^{4}$, Prasad S.K ${ }^{5}$ \\ ${ }^{1}$ B.E Final year, Civil Engineering, Sri Jayachamarajendra College of Engineering, Mysore, Karnataka, India \\ ${ }^{2}$ B.E Final year, Civil Engineering, Sri Jayachamarajendra College of Engineering, Mysore, Karnataka, India \\ ${ }^{3}$ B.E Final year, Civil Engineering, Sri Jayachamarajendra College of Engineering, Mysore, Karnataka, India \\ ${ }^{4}$ B.E Final year, Civil Engineering, Sri Jayachamarajendra College of Engineering, Mysore, Karnataka, India \\ ${ }^{5}$ Professor of Civil Engineering, Sri Jayachamarajendra College of Engineering, Mysore, Karnataka, India
}

\begin{abstract}
Earthquake refers to the sudden release of energy in the earth's crust that creates seismic waves. Earthquakes are unpredictable and their intensity attenuates over long distances. In an idealized situation earth is considered to be elastic and the seismic waves can propagate indefinitely once they are excited. But it is known that the real earth is not perfectly elastic. This causes the waves that are propagating to attenuate with time as they travel. Uncertainties persist in the attenuation equations as they depend on many factors such as epicentral distance, focal depth, geology, fault characteristics, magnitude, topography etc. Many attenuation equations have been developed over the years considering various factors. The present work focuses on validating and critically comparing popular attenuation equations such as Sarma (2000), Smit (2000), Tento(1992), Jacob(1990) etc. for earthquake data of recent times (2005 onwards). An attempt is made to collect as much information as possible from different stations during different earthquakes. The accuracy and effectiveness of different attenuation equations are verified. Also attempt is made to study the sensitiveness of different factors influencing the seismicity. Further it has been inferred that each formula has its own merits and demerits and an attempt is made to identify the most effective attenuation formula for wide range of earthquake data.
\end{abstract}

Keywords: Attenuation Equations, Epicentral Distance, Focal depth and Magnitude.

\section{INTRODUCTION}

The ground motion attenuation equation is a mathematical equation or engineering model that relates a strong motion parameter to one or more parameters of the earthquake source, wave propagation path and local site conditions. It provides the background for seismic resistant design, seismic zonation map and seismic hazard analysis. Ground motion attenuation equations depend on many parameters such as epicentral distance, focal depth, geology, fault characteristics, magnitude, topography etc. As the attenuation equation depends on many parameters, the equations are associated with uncertainties. An important statistical issue in developing ground motion attenuation equation is the uneven sampling of the data from different earthquakes. For example in some cases, an earthquake may have only one or two recordings (e.g., 1940 EI Centre event), whereas some of the recent earthquakes have hundreds of recordings (e.g., 1999 Chi-Chi earthquake).

Ground shaking is the most important cause to damage during earthquakes. When an earthquake occurs, seismic waves radiate away from the source and travel rapidly through the earth's crust. When the waves reach the ground surface, they produce shaking which may last from seconds to minutes.
Estimating seismic ground shaking is an important step in anticipating earthquake effects on people and structures. Earthquakes can cause damage, casualties and destruction mainly in four ways. First, vibratory ground shaking may cause damage to natural and artificial structures and may cause ground failure. Second, rupture of the fault at the ground surface and underground may cause damage to structures in the immediate area. Third, uplifting of material in the fault region may cause damage, perhaps in conjunction with ocean or rivers. It may block rives or change their paths. Fourth, tsunamis or seiches may inundate coastal regions or other regions near to water, causing damage. Therefore, much work has been done to reduce the losses generated by ground shaking. Ground motion attenuation relationships could be considered as one field of these kinds of work.

When a large earthquake occurs, an earthquake early warning (EEW) system can alert populations, sensitive facilities such as nuclear reactors, gas pipelines, and public transportation systems, ahead of the arrival of strong ground shaking. An early warning leading time can be a few seconds to a few tens of seconds depending on the distance between the earthquake and the target warning areas. Therefore for the effective risk mitigation the ground motion attenuation equation is necessary for the proper assessment of magnitude and peak ground 
acceleration at every location. Further, the magnitude and peak ground acceleration so obtained from ground motion attenuation equation will also be helpful for inculcating safety in the design of earthquake resistant structures.

\section{ATTENUATION EQUATIONS}

The following attenuation equations are considered in the present study.

\subsection{Smit et al. (2000)}

$$
\log A=\mathbf{a}+\mathbf{b M}-\log \mathbf{R}+\mathbf{d R}
$$

Here, $\mathrm{A}$ is PGA in $\mathrm{cms}^{-2}, \mathrm{R}$ is epicentral distance in $\mathrm{km}, \mathrm{M}$ is moment magnitude, $\mathrm{a}=0.72, \mathrm{~b}=0.44, \mathrm{~d}=-0.00231$.

\section{Remarks:}

- Records can be from soil or alluvium sites.

- For near field earthquakes.

- Note that scatter can be reduced by increasing number of records used (especially in near field), improving all seismological and local site parameters and increasing number of variables (especially in near field and those modeling local site behavior) but that this requires much more information than is available.

\subsection{Dahle et al. (1990)}

$$
\ln \mathrm{A}=\mathrm{C}_{1}+\mathrm{C}_{2} \mathrm{M}+\mathrm{C}_{4} \mathrm{R}+\ln \mathrm{G}\left(\mathrm{R}, \mathrm{R}_{0}\right)
$$

Here, $G(R, R)=R^{-1}$ for $R \leq R_{0}$

$$
\text { And } G\left(R, R_{0}\right)=R_{0}^{-1}\left(R_{0} / R\right)^{5 / 6} \quad \text { for } R>R_{0}
$$

Here, $\mathrm{A}$ is PGA in $\mathrm{ms}^{-2}, \mathrm{M}$ is moment magnitude, $\mathrm{R}$ is epicentral distance in $\mathrm{km}, \mathrm{C}_{1}=-1.471, \mathrm{C}_{2}=0.849, \mathrm{C}_{4}=$ $-0.00418, \mathrm{R}_{0}=100 \mathrm{~km}$.

\section{Remarks:}

- Records shall be from rock sites (presumably with hard rock or firm ground conditions).

- Convenient for tectonically stable and geologically more uniform areas (eastern North America, Australia and some parts of Europe) intraplate areas.

- Suitable records that are unprocessed and those with sufficient information on natural frequency and damping of instrument.

- Applicable for most (72\%) records from earthquakes with $\mathrm{M} \leq 5.5$

- Correlation coefficient between magnitude and distance achieved is 0.31 .

- If the focal depth is unknown, it can be assumed as 15 $\mathrm{km}$.

Choose $\mathrm{R}_{0}=100 \mathrm{~km}$ although depends on crustal structure and focal depth.

\subsection{Jacob et al. (1990)}

$$
A=10^{(a 1+a 2 M+a 3 \log d+a 4 d)}
$$

Here, $\mathrm{A}$ is PGA in $\mathrm{g}, \mathrm{M}$ is moment magnitude, $\mathrm{d}$ is epicentral distance in $\mathrm{km}, \mathrm{a} 1=-1.43, \mathrm{a} 2=0.31, \mathrm{a} 3=-0.62$ and $\mathrm{a} 4=$ -0.0026 .

\section{Remarks:}

- Careful assessment of uncertainties is required.

- Equation has been used only for hard rock sites.

- Regressions are preliminary and should be tested against more data.

\subsection{Ambraseys et al. (1992)}

$$
\log (\mathrm{A})=\mathrm{C}_{1}+\mathrm{C}_{2} \mathrm{M}+\mathrm{C}_{3} \mathrm{r}+\mathrm{C}_{4} \log \mathrm{r}
$$

$\mathrm{r}=\left(\mathrm{d}^{2}+\mathrm{h}_{\mathrm{o}}^{2}\right)^{0.5}$

Here, $\mathrm{A}$ is PGA in $\mathrm{g}, \mathrm{M}$ is moment magnitude, $\mathrm{d}$ is epicentral distance in $\mathrm{km}, \mathrm{C}_{1}=-1.038, \mathrm{C}_{2}=0.220, \mathrm{C}_{3}=-0.00149, \mathrm{C}_{4}=$ $-0.895, \mathrm{~h}_{0}=5.7 \mathrm{~km}$.

\section{Remarks:}

- Coefficients given above are for the earthquake data of 1985 with recalculated magnitudes and distances and addition of extra records from some earthquakes.

\subsection{Sigbjornsson \& Baldvinsson (1992)}

$\log \mathbf{A}=\alpha+\beta M-\log R+b R$

Here, $R=\left(d^{2}+h^{2}\right)^{0.5}$

Here, $\mathrm{A}$ is PGA in $\mathrm{g}, \mathrm{M}$ is moment magnitude, $\mathrm{d}$ is epicentral distance in $\mathrm{km}, \mathrm{h}$ is focal depth in $\mathrm{km}$, for average horizontal PGA and $4<\mathrm{M}<6 \alpha=-1.98, \beta=0.365, \mathrm{~b}=-0.0039$, for larger horizontal PGA and $4<\mathrm{M}<6 \alpha=-1.72, \beta=0.327, \mathrm{~b}=$ -0.0043 and for both horizontal PGAs and $2<\mathrm{M}<6 \alpha=$ $-2.28, \beta=0.386, b=0$.

\section{Remarks:}

- Icelandic data does not fit the equation.

- Equation uses records only with $\mathrm{M} \geq 4.0$, h equal to focal depth and larger horizontal component.

\subsection{Tento et al. (1992)}

$$
\ln A=b_{1}+b_{2} M+b_{3} R-\ln R
$$

Here, $\mathrm{A}$ is PGA in gal, $\mathrm{R}=\left(\mathrm{d}^{2}+\mathrm{h}^{2}\right)^{0.5}, \mathrm{M}$ is moment magnitude, $d$ is the epicentral distance in $\mathrm{km}$ and $\mathrm{h}$ is the focal depth in $\mathrm{km}, \mathrm{b}_{1}=4.73, \mathrm{~b}_{2}=0.52, \mathrm{~b}_{3}=-0.00216$

- Most records are from epicentral distances between 10 $\mathrm{km}$ and $40 \mathrm{~km}$.

- Cutoff frequencies range between $0.13 \mathrm{~Hz}$ and $1.18 \mathrm{~Hz}$ with a median of $0.38 \mathrm{~Hz}$. 
- Records included from analysis are from free-field stations. Excluded those with epicentral distances greater than that of first non triggered station.

- Using $d$ instead of $\mathrm{R}$ causes greater scatter in data.

- Moderate underestimation for low magnitude in near field and for high magnitude in far field.

\subsection{Sarma \& Srbulov (1996)}

$$
\log \left(A_{P}\right)=b_{1}+b_{2} M+b_{3} \log r+b_{4} r
$$

Here, $r=\left(d^{2}+h_{o}{ }^{2}\right)^{0.5}$

Here $A_{P}$ is in $g, M$ is moment magnitude, $d$ is epicentral distance in $\mathrm{km}$, using both horizontal components $\mathrm{b}_{1}=-1.617$, $\mathrm{b}_{2}=0.248, \mathrm{~b}_{3}=-0.5402, \mathrm{~b}_{4}=-0.00392, \mathrm{~h}_{0}=3.2 \mathrm{~km}$ and for larger horizontal component $b_{1}=-1.507, b_{2}=0.240, b_{3}=$ $-0.542, \mathrm{~b}_{4}=-0.00397, \mathrm{~h}_{0}=3.0 \mathrm{~km}$.

\section{Remarks:}

- Applicable for focal depths between 2 and $29 \mathrm{~km}$.

- Topography is not an influencing factor.

- Most records taken are from Western USA, Europe and Middle East.

- Two soil categories are considered, namely, soil and rock.

\subsection{Jain et al. (2000)}

$$
\ln A=b_{1}+b_{2} M+b_{3} R+b_{4} \ln (R)
$$

Here, $\mathrm{A}$ is $\mathrm{PGA}$ is in $\mathrm{g}, \mathrm{M}$ is moment magnitude, $\mathrm{R}$ is epicentral distance in $\mathrm{km}$, for central Himalayan earthquakes $\mathrm{b}_{1}=-4.135, \mathrm{~b}_{2}=0.647, \mathrm{~b}_{3}=-0.00142, \mathrm{~b}_{4}=-0.753$ and $\mathrm{b}_{1}=$ $-3.443, b_{2}=0.706, b_{3}=0, b_{4}=-0.828$.

\section{Remarks:}

- Limited details of fault rupture are available. Hence, epicentral distance is the convenient data.

- Use of epicentral locations gives best correlation between distance and PGA.

- Considerable scatters are found between predicted PGA in different regions.

- Data split into four categories for which separate equations are derived:

$>$ Central Himalayan earthquakes (thrust): (32 SMA records, 117 SRR records), 3 earthquakes with $5.5 \leq \mathrm{M} \leq 7.0$, focal depths $10 \leq \mathrm{h} \leq 33 \mathrm{~km}$ and epicentral distances $2 \leq \mathrm{R} \leq 322 \mathrm{~km}$.

$>$ Non-subduction earthquakes in NE India (thrust): (43 SMA records, 0 SRR records), 3 earth- quakes with $5.2 \leq \mathrm{M} \leq 5.9$, focal depths $33 \leq \mathrm{h} \leq 49 \mathrm{~km}$ and epicentral distances $6 \leq \mathrm{R} \leq$ $243 \mathrm{~km}$.

$>$ Subduction earthquakes in NE India: (33 SMA records, 104 SRR records), 1 earthquake with $M$

$=7.3$, focal depth $\mathrm{h}=90 \mathrm{~km}$ and epicentral distances $39 \leq \mathrm{R} \leq 772 \mathrm{~km}$.

$>$ Bihar-Nepal earthquake in Indo-Gangetic plains (strike-slip): (0 SMA records, 38 SRR records), 1 earthquake with $\mathrm{M}=6.8$, focal depth $\mathrm{h}=$ $57 \mathrm{~km}$ and epicentral distances $42 \leq \mathrm{R} \leq 337 \mathrm{~km}$.

\section{LIST OF EARTHQUAKE DATA CONSIDERED IN THE PRESENT WORK}

\begin{tabular}{|c|c|c|c|c|c|}
\hline $\begin{array}{l}\text { Sl } \\
\text { no }\end{array}$ & $\begin{array}{l}\text { Name of } \\
\text { earthquake }\end{array}$ & Date & UTC & $\mathbf{M}$ & $\begin{array}{c}\begin{array}{c}\text { Focal } \\
\text { depth } \\
(\mathbf{k m})\end{array} \\
\end{array}$ \\
\hline 1 & Parkfield & 28-09-2004 & $17: 15$ & 6 & 7.9 \\
\hline 2 & Anza & $12-06-2005$ & $15: 40$ & 5.2 & 14.1 \\
\hline 3 & Dillon & $26-07-2005$ & 04:08 & 5.6 & 5 \\
\hline 4 & $\begin{array}{c}\text { Obsidian } \\
\text { butte }\end{array}$ & 02-09-2005 & $01: 27$ & 5.1 & 9.7 \\
\hline 5 & Mettler & $16-04-2005$ & $19: 18$ & 4.6 & 10.2 \\
\hline 6 & Ocotillo wells & 21-05-2005 & 00:39 & 4.1 & 15 \\
\hline 7 & $\begin{array}{c}\text { South of } \\
\text { Huwai island }\end{array}$ & $17-07-2005$ & $19: 15$ & 5.2 & 28.4 \\
\hline 8 & Kiholo bay & $15-10-2006$ & $17: 07$ & 6.7 & 38.9 \\
\hline 9 & Mahukona & $15-10-2006$ & $17: 15$ & 6 & 18.09 \\
\hline 10 & $\mathrm{Na}$ Alehu & 19-01-2006 & 02:04 & 4.7 & 40 \\
\hline 11 & Ocotillo & 03-11-2006 & $15: 56$ & 4.2 & 13.7 \\
\hline 12 & $\begin{array}{l}\text { Offshore of } \\
\text { Northern } \\
\text { California }\end{array}$ & $26-02-2007$ & $12: 19$ & 5.4 & 0.4 \\
\hline 13 & The Geysers & 24-04-2007 & $21: 08$ & 4.4 & 1.7 \\
\hline 14 & Alum rock & 31-10-2007 & 03:04 & 5.4 & 9.2 \\
\hline 15 & O Okala & 05-02-2007 & $15: 35$ & 3.5 & 9.3 \\
\hline 16 & $\begin{array}{c}\text { West of } \\
\text { Trinidad }\end{array}$ & 25-06-2007 & $02: 38$ & 05 & 10.1 \\
\hline 17 & California 1 & $28-12-2008$ & $05: 17$ & 4.2 & 10 \\
\hline 18 & Mexico & $30-12-2009$ & $18: 48$ & 5.8 & 6 \\
\hline 19 & Skwenta & 22-06-2009 & $19: 28$ & 5.4 & 52.7 \\
\hline 20 & California 2 & 08-06-2010 & $17: 39$ & 04 & 7.7 \\
\hline 21 & Arkansas & 27-02-2011 & 05:00 & 4.7 & 3.8 \\
\hline 22 & Oklahoma & 11-05-2011 & $03: 53$ & 5.6 & 5 \\
\hline 23 & Virginia & 23-08-2011 & $17: 51$ & 5.8 & 6 \\
\hline 24 & California 3 & 01-11-2011 & 08:51 & 4.5 & 8.4 \\
\hline 25 & Hawai & 24-02-2012 & $13: 52$ & 4.3 & 5.9 \\
\hline 26 & Missouri & 21-02-2012 & 09:58 & 3.9 & 7.9 \\
\hline 27 & California 4 & 13-02-2012 & 21:07 & 5.6 & 32.9 \\
\hline
\end{tabular}

Table-1: List of earthquake data. 


\section{RESULTS AND DISCUSSIONS:}

In the present work a total of 8 ground motion attenuation equations developed empirically are selected as detailed in Table 4. Table 2 provides the earthquake data from a wide range of earthquakes with varying magnitudes, focal depths, epicentral distances and fault types collected 2005 onwards for the attenuation equation developed by Smit et al. 2000. PGA for different earthquake data are calculated using the ground motion attenuation equations. PGA so obtained are compared with the recorded PGA of the earthquake data. Further, various factors affecting the ground motion attenuation equations are considered. It can be observed that the variation ranges from $-39.66 \%$ to $+59.6 \%$. Fig-1 shows the average error in PGA from different stations obtained from the attenuation equation developed by Smit et al. 2000 for different earthquake data. Fig-2 presents the map of Oklahoma in USA with locations of many seismic recording stations from which the earthquake data is available. Fig-3 provides a typical ground motion recorded from one of the recording stations in Oklahama. The ground motion includes three components, namely north - south, east - west and up - down components. Table 3 presents the summary of the analysis carried out for different earthquake data from eight attenuation equations. This includes the range of error between the actual recorded and computed PGA and the statistical average error in PGA. It can be observed that Smit et al. (2000) and Sigbjornsson \& Baldvinsson (1992) provide the best results. Table 4 gives the summary of the factors considered in the computation of PGA in each of the eight attenuation equations considered in the present study.

Table-2: PGA computed from attenuation equation (Smit et al. 2000) for different earthquake data.

\begin{tabular}{|c|c|c|c|}
\hline SI no & $\begin{array}{c}\text { PGA } \\
\text { recorded }\end{array}$ & $\begin{array}{c}\text { PGA } \\
\text { computed }\end{array}$ & $\begin{array}{c}\text { Percentage } \\
\text { error }\end{array}$ \\
\hline 1 & 170 & 185.6 & -9.21 \\
\hline 2 & 200 & 194.37 & 2.8 \\
\hline 3 & 7.1 & 6.98 & 1.58 \\
\hline 4 & 70.8 & 76.7 & -8.33 \\
\hline 5 & 14 & 14.6 & -4.42 \\
\hline 6 & 4.9 & 5.65 & -15.46 \\
\hline 7 & 11.3 & 10.12 & 10.38 \\
\hline 8 & 178 & 248.6 & -39.66 \\
\hline 9 & 33 & 31.3 & 5.12 \\
\hline 10 & 28 & 33.19 & -18.55 \\
\hline 11 & 5.8 & 5.09 & 12.23 \\
\hline 12 & 18.5 & 18.23 & 1.42 \\
\hline 13 & 55.8 & 35.56 & 4.02 \\
\hline 14 & 103 & 109.05 & -5.87 \\
\hline 15 & 9.3 & 3.75 & 59.6 \\
\hline 16 & 6.2 & 6.44 & -3.9 \\
\hline 17 & 42.2 & 28.4 & 32.67 \\
\hline 18 & 84.1 & 42.2 & 49.8 \\
\hline
\end{tabular}

\begin{tabular}{|c|c|c|c|}
\hline 19 & 12.6 & 8.35 & 33.71 \\
\hline 20 & 14.2 & 18.99 & -33.79 \\
\hline 21 & 2 & 1.18 & 39.12 \\
\hline 22 & 16.9 & 15.6 & 7.6 \\
\hline 23 & 2.86 & 1.89 & 33.61 \\
\hline 24 & 6.9 & 9.74 & -41 \\
\hline 25 & 9.08 & 8.91 & 1.85 \\
\hline 26 & .9 & 1.029 & -14.42 \\
\hline 27 & 21.8 & 19.84 & 9.01 \\
\hline
\end{tabular}

,

\section{Smit et al (2000)}

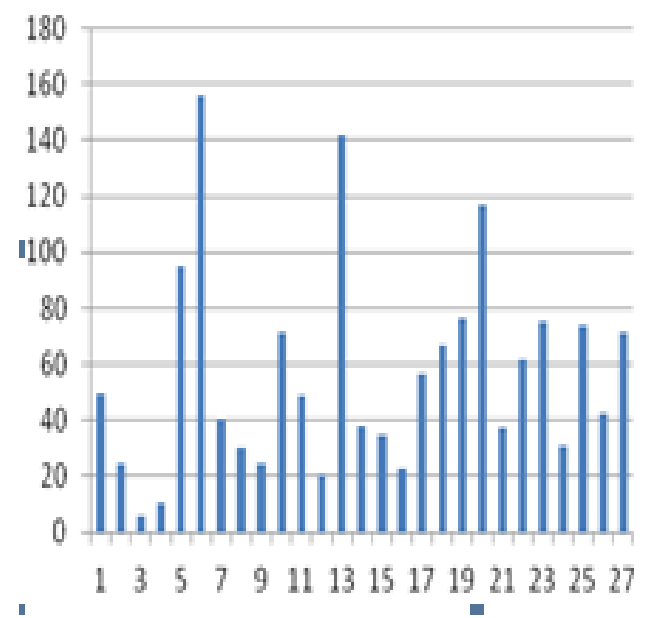

Fig-1: Average error in PGA computed for different earthquakes.

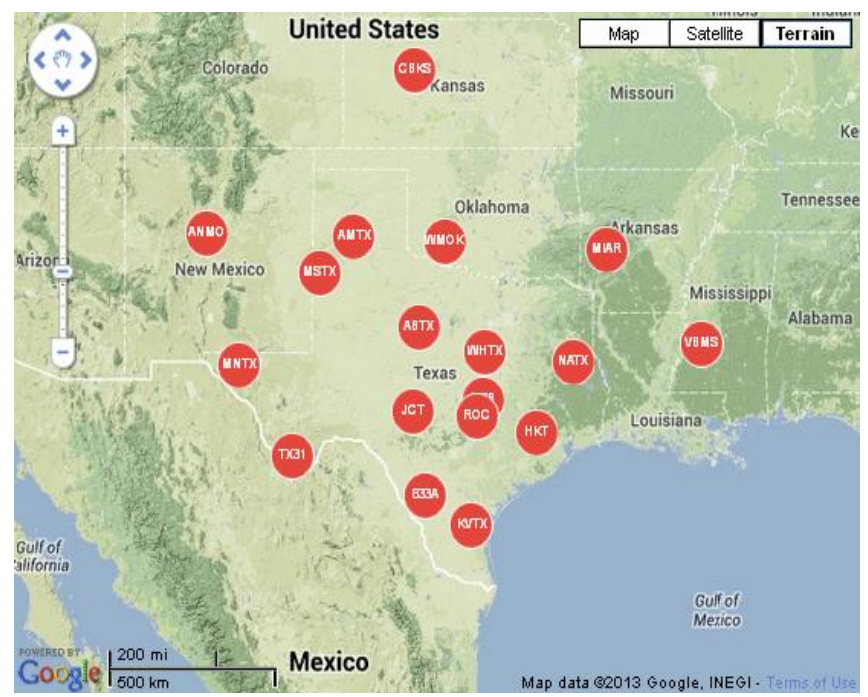

Fig-2: Seismic recording stations spread around Oklahoma. 


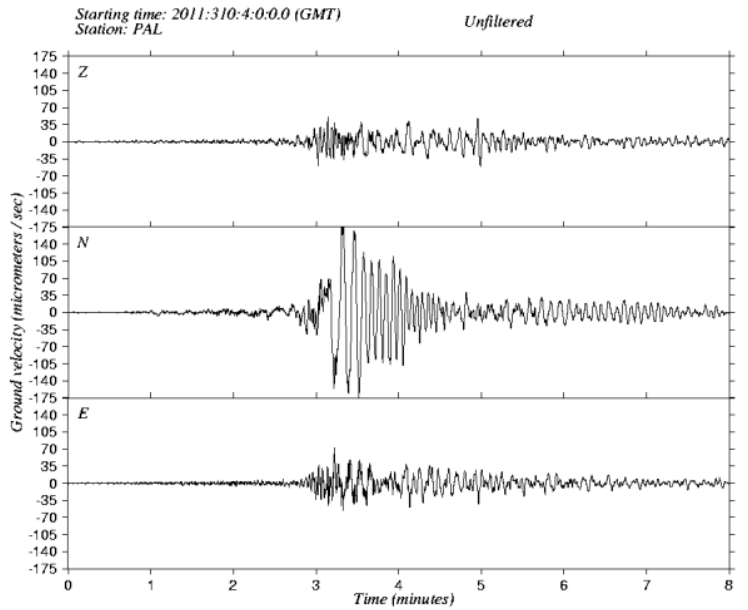

Fig-3: Ground velocity recording of Oklahoma earthquake.

Table-3: Average error and range of error in PGA for different earthquakes.

\begin{tabular}{|c|c|c|c|}
\hline $\begin{array}{c}\text { SI } \\
\text { no }\end{array}$ & Method & $\begin{array}{c}\text { Range of } \\
\text { error in } \\
\text { PGA }\end{array}$ & $\begin{array}{c}\text { Average } \\
\text { error in } \\
\text { PGA }\end{array}$ \\
\hline 1 & Smit et al. (2000) & $\begin{array}{c}-156.1 \text { to } \\
76.42\end{array}$ & -13.66 \\
\hline 2 & $\begin{array}{c}\text { Dahle et al. } \\
\text { (1990b) \& Dahle } \\
\text { et al. (1990a) }\end{array}$ & $\begin{array}{c}-588.84 \text { to } \\
62.26\end{array}$ & -165.54 \\
\hline 3 & Jacob et al. (1990) & $\begin{array}{c}-32.06 \text { to }- \\
1576.46\end{array}$ & -622.71 \\
\hline 4 & $\begin{array}{c}\text { Ambraseys et al. } \\
\text { (1992) }\end{array}$ & $\begin{array}{c}-587.9 \text { to } \\
61.4\end{array}$ & -155.9 \\
\hline 5 & $\begin{array}{c}\text { Sigbjornsson \& } \\
\text { Baldvinsson } \\
\text { (1992) }\end{array}$ & $\begin{array}{c}-74.2 \text { to } 87.9 \\
24.91\end{array}$ \\
\hline 6 & $\begin{array}{c}\text { Tento et al. (1992) } \\
-7\end{array}$ & $\begin{array}{c}-598.4 \text { to } \\
76.5\end{array}$ & -152.28 \\
\hline 8 & Jaina \& Srbulov & -576.63 to \\
(1996) & -162.2 & -167 \\
\hline
\end{tabular}

\section{CONCLUSIONS}

The following inferences are drawn from the present study:

- Most of the ground motion attenuation equations are developed based on empirical approaches. These equations mainly depend on primary factors such as epicentral distance and magnitude of earthquake. Some of the equations also depend on focal depth, fault type, type of earthquake and near / far field effects. (Table4)
- Out of all the factors influencing the ground motion attenuation equations the most predominant factors are epicentral distance and magnitude of earthquake. Factors such as focal depth, fault type and type of earthquake also influence the ground motion attenuation equation, but to a smaller extent.

- It is found that the ground motion attenuation equation developed by Jain et al. (2000) is complex to handle as it considers the type of earthquake (Subduction and Non-Subduction), whereas the attenuation equation developed by Smit et al.(2000) is simple.

- Further, the attenuation equations developed by Smit et al. (2000) and Sigbjornsson \& Baldvinsson (1992) gave better results for the earthquake data used in the present study.

\section{REFERENCES}

[1] J. Douglas (2001), "A comprehensive worldwide summary of strong-motion attenuation relationships for peak ground acceleration and spectral ordinates (1969 to 2000)", ESEE Report No. 01-1.

[2] K. Campbell (2005), "Uncertainties in the attenuation laws", 2nd Workshop on Earthquake Engineering for Nuclear Facilities: Uncertainties in Seismic Hazard.

[3] C. Pasolini, P. Gasperini, D. Albarello, B. Lolli, and V. D'Amico (2008),"The Attenuation of Seismic Intensity in Italy, Part I:Theoretical and Empirical Backgrounds", Seismological Society of America, Vol. 98, No. 2, pp. 682-691.

[4] United States Geological Survey (USGS).

\section{BIOGRAPHIES}

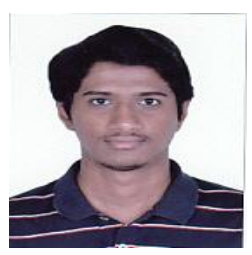

Rajaram Vailaya S (Final year B.E) in Civil Engineering

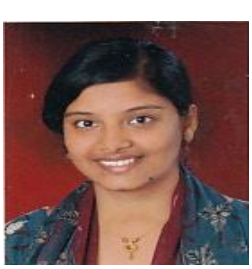

Manasa (Final year B.E) in Civil Engineering

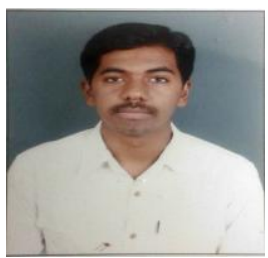

Achyutha Bharadwaj S (Final year B.E) in Civil Engineering 


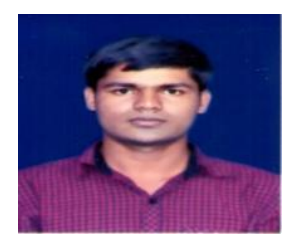

Sumanthu (Final year B.E) in Civil

Engineering

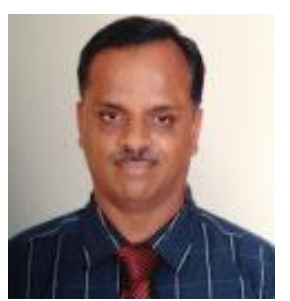

Dr. S.K.Prasad (Professor of Civil

Engineering, SJCE , Mysore)

Table-4: Various factors influencing the ground motion attenuation equation.

\begin{tabular}{|c|c|c|c|c|c|c|c|c|c|}
\hline $\begin{array}{l}\text { SL } \\
\text { NO }\end{array}$ & $\underset{\mathbf{N}}{\text { EQUATIO }}$ & $\begin{array}{c}\text { MAGNITU } \\
\text { DE }\end{array}$ & $\begin{array}{c}\text { EPICENT } \\
\text { RAL } \\
\text { DISTANC } \\
\text { E } \\
\end{array}$ & $\begin{array}{c}\text { FOCA } \\
\text { L } \\
\text { DEPT } \\
\text { H } \\
\end{array}$ & $\begin{array}{c}\text { SOIL } \\
\text { TYP } \\
\text { E }\end{array}$ & $\begin{array}{l}\text { FAUL } \\
\text { T } \\
\text { TYPE }\end{array}$ & PGA & $\begin{array}{c}\text { TYPE OF } \\
\text { EARTHQUA } \\
\text { KE }\end{array}$ & $\begin{array}{c}\text { NEAR / FAR } \\
\text { FIELD } \\
\text { EFFECTS }\end{array}$ \\
\hline 1 & $\begin{array}{l}\text { Smit et al. } \\
(2000)\end{array}$ & $\checkmark$ & $\checkmark$ & $x$ & $\checkmark$ & $x$ & $\checkmark$ & $x$ & $\checkmark$ \\
\hline 2 & $\begin{array}{l}\text { Dahle et al. } \\
\text { (1990b) \&. } \\
\text { (1990a) }\end{array}$ & $\checkmark$ & $\checkmark$ & $x$ & $\checkmark$ & $x$ & $\checkmark$ & $x$ & $x$ \\
\hline 3 & $\begin{array}{c}\text { Jacob et al. } \\
\text { (1990) }\end{array}$ & $\checkmark$ & $\checkmark$ & $x$ & $\checkmark$ & $x$ & $\checkmark$ & $x$ & $x$ \\
\hline 4 & $\begin{array}{l}\text { Ambraseys } \\
\text { et al. (1992) }\end{array}$ & $\checkmark$ & $\checkmark$ & $\checkmark$ & $x$ & $x$ & $\checkmark$ & $x$ & $x$ \\
\hline 5 & $\begin{array}{c}\text { Sigbjornsson } \\
\& \\
\text { Baldvinsson } \\
(1992)\end{array}$ & $\checkmark$ & $\checkmark$ & $\checkmark$ & $x$ & $x$ & $\checkmark$ & $x$ & $x$ \\
\hline 6 & $\begin{array}{l}\text { Tento et al. } \\
\text { (1992) }\end{array}$ & $\checkmark$ & $\checkmark$ & $\checkmark$ & $x$ & $x$ & $\checkmark$ & $x$ & $\checkmark$ \\
\hline 7 & $\begin{array}{c}\text { Sarma \& } \\
\text { Srbulov } \\
\text { (1996) }\end{array}$ & $\checkmark$ & $\checkmark$ & $x$ & $\checkmark$ & $x$ & $\checkmark$ & $x$ & $x$ \\
\hline 8 & $\begin{array}{c}\text { Jain et al. } \\
(2000)\end{array}$ & $\checkmark$ & $\checkmark$ & $x$ & $x$ & $x$ & $\checkmark$ & $\checkmark$ & $x$ \\
\hline
\end{tabular}

$\checkmark$ Factor considered, $\times$ Factor not considered 